The Party and Agricultural

Crisis Management in the USSR 
Studies in SOviet History And SOCIETy

edited by Joseph S. Berliner, Seweryn Bialer, and Sheila Fitzpatrick

Research Guide to the Russian and Soviet Censuses edited by Ralph S. Clem

The Party and Agricultural Crisis Management in the USSR by Cynthia S. Kaplan

Will the Non-Russians Rebel? State, Ethnicity, and Stability in the USSR by Alexander J. Motyl

Revolution on the Volga: 1917 in Saratov by Donald J. Raleigh 


\section{The Party and}

Agricultural Crisis

Management in the USSR

CYNTHIA S. KAPLAN

CORNELL UNIVERSITY PRESS

Ithaca and London 
Copyright (C) 1987 by Cornell University

All rights reserved. Except for brief quotations in a review, this book, or parts thereof, must not be reproduced in any form without permission in writing from the publisher. For information, address Cornell University Press, 124 Roberts Place, Ithaca, New York 14850.

First published 1987 by Cornell University Press.

International Standard Book Number 0-8014-2021-0

Library of Congress Catalog Card Number 86-32223

Printed in the United States of America

Librarians: Library of Congress cataloging information appears on the last page of the book.

The paper in this book is acid-free and meets the guidelines for permanence and durability of the Committee on Production Guidelines for Book Longevity of the Council on Library Resources. 
In honor of my parents,

Harold Kaplan and Ann Goodman Kaplan, and my sister, Sharon T. Kaplan 
Digitized by the Internet Archive in 2018 with funding from The Arcadia Fund 